\title{
Residents' quality of life and attitudes toward tourism development in China
}

\begin{abstract}
The purpose of this study is to explore the influence of quality of life and residential status on resident attitudes toward further tourism development. The measurement of tourism and quality of life (TQOL) is modified. Using a sample of 562 residents from Shenzhen OCT community of China, this study has identified six TQOL domains and examines the effects of each TQOL domains based on the residential status and residents' attitudes in supporting further tourism development. The results reveal that the positive supporting attitudes of residents depends on the selected TQOL domains, especially on non-material improvements of TQOL. Tenants and dormitory residents have more positive attitudes than those house owners. This study also identifies four resident clusters with different attitudes and it is found that the residents' attitudes of tourism development depend on whether they perceive the community as a place for earning a living or a place to live.
\end{abstract}

Keywords: Tourism development; Quality of Life (QOL); Community resident; Attitudes toward further tourism development; Shenzhen Oversea Chinese Town (OCT), China.

\section{Introduction}

The development of tourism is an increasingly popular option for community regeneration. Tourism has been found to stimulate local economies (Sharpley \& Telfer, 2002), attract foreign investment (Liu et al., 1987; Sheng \& Tsui, 2010), increase business activity (Prentice, 1993), enhance land value (Crompton, 2004), improve community infrastructure (Mathieson et al., 1982), and attract the wealthy middle class (Gotham, 2005; Liang \& Bao, 2015). However, once a community becomes a tourist destination, the daily lives of its residents are transformed by the presence of increasing numbers of visitors and tourist-oriented activities (Jurowski et al., 1997) depending on the stage of tourism development in their community (Kim et 
al., 2013). Over the past decade, the effects of tourism development on QOL have received considerable attention (Woo et al., 2015), focusing on two directions. In one direction, scholars tested the relationship between tourists' QOL and travel experiences or behavior (e.g. Neal et al., 1999; Lloyd \& Auld, 2002; Gilbert \& Abdullah, 2004; Neal et al., 2007; Sirgy, 2010; Sirgy et al., 2011; Dolnicar et al., 2012; Chen et al., 2013; de Bloom et al., 2013; Kruger et al., 2013; McCabe \& Johnson, 2013; Bimonte \& Faralla, 2014; Kim et al., 2015). In the other direction, scholars focused on tourism development and its effects on the QOL of residents in tourist destinations (Allen et al., 1988; Andereck et al., 2007; Andereck \& Nyaupane, 2011; Aref, 2011; Budruk \& Phillips, 2011; Filep et al., 2011; Nawijn \& Mitas, 2012; Guo et al., 2013; Kim et al., 2013; Moscardo et al., 2013; Wu \& Pearce, 2013; Buzinde et al., 2014; Woo et al., 2015).

This study investigates the second direction. Kim et al. (2013) proposed that residents' perception of tourism influences their sense of well-being in four domains: their material, community, and emotional life, and their health and safety. Residents' sense of well-being in those life domains affects their overall satisfaction with life. Andereck et al. (2007) constructed the tourism and quality of life (TQOL) measurement scale to explain the relationship between tourism development and QOL. Andereck and Nyaupane (2011) further developed the TQOL and identified eight domains: community well-being, urban issues, way of life, community pride and awareness, natural/cultural preservation, economic strength, recreation amenities, and crime and substance abuse. These life domains can be divided into material and non-material domains (Woo et al., 2015). The TQOL indicators measured perceptions of tourism effects on QOL with more clarity but were incomplete as they excluded some widely accepted indicators of QOL, such as health and family life (see Cummins, 1996; Nawijn \& Mitas, 2012; Kim et al., 2013; McCabe \& Johnson, 2013; Woo et al., 2015).

There was a consensus that QOL/TQOL influenced residents' attitudes toward 
future tourism development in their communities (e.g. Liu \& Var, 1986; Ap, 1992; Lankford \& Howard, 1994; Gursoy et al., 2002; Teye et al., 2002; Nawijn \& Mitas, 2012; Woo et al., 2015). This varying level of satisfaction leads to changes in attitudes toward tourism development. Normally, those residents with a higher rate of overall satisfaction with their QOL would exhibit a positive attitude (Andereck \& Nyaupane, 2011; Woo et al., 2015). However, which domains of QOL/TQOL can best predict residents' attitudes? The specific context of a case is important. In most early studies, the community population composition of a selected case is relatively simple. However, in Shenzhen OCT community in China which is at mature stage of tourism development and has diverse population, different attitudes are perceived. Moreover, in China, family life plays a significant role on in the evaluation of QOL (Shek \& Lee, 2007). Individual attitudes of Chinese people are also highly related to the family value and residential status. How about the predictive effects of family life domain and residential status on residents' attitudes?

In brief, the main objective of this paper are two folds. First, we would like to investigate whether different TQOL domains, demographics and the residential status have any impact on the attitude toward future tourism development. Second, we would also like to see how many attitude groups are there in a mutual and diverse tourism community? And whether different groups of residents have different attitudes towards the differences in TQOL domains. All these results may help the community officials and planners to set up a better guideline and so enhance a more effectiveness of practices in tourism and community development.

\section{Literature review}

\subsection{Tourism and QOL: Studies and measurements}

In recent years, the non-economic measures of tourism development, such as QOL, have become the focus of tourism impact research (Uysal et al., 2012). Meanwhile, more and more communities are developing tourism with the goal of enhancing residents' QOL. There are two broad types of indicators for measuring QOL. One 
provides a direct measure of subjective reactions; the other is based on a series of objective indicators, such as crime rates, population densities, and unemployment figures (Andrews, 1974). Subjective indicators are widely applied in tourism research (e.g. Andereck \& Nyaupane, 2011; Kim et al., 2013; Buzinde et al., 2014; Kim et al., 2015; Woo et al., 2015), including Subjective Well-being (SWB) (McCabe et al., 2010; Nawijn \& Mitas, 2012; McCabe \& Johnson, 2013), Life Satisfaction (LS) (Dolnicar et al., 2012; Kim et al., 2013; Kim et al., 2015) and Happiness (Nawijn, 2011; Bimonte \& Faralla, 2014). SWB comprises a global assessment of all domains of a person's life (Diener, 1984), including both cognitive judgments and affective reactions. Happiness contributes to affective SWB while LS measures cognitive SWB (Campbell et al., 1976; Veenhoven, 1991; McCabe \& Johnson, 2013). Therefore, SWB is a comprehensive and effective approach to understanding QOL under the influence of tourism.

Most studies consider SWB to be composed of several domains. Total SWB can be measured through a series of individual life domains (Andrews \& Withey, 1976; Campbell et al., 1976). Cummins (1996) grouped 173 different life domains derived from the early literature and identified seven of the most used ones: material well-being, health, productivity, intimacy, safety, community, and emotional well-being. These seven domains of SWB were accepted and applied not only in academic QOL research, but also in tourism research (e.g. Kim et al., 2013; Moscardo et al., 2013; Woo et al., 2015). Most of the aforementioned researchers modified the seven domains and the specific measurement items according to the particulars of the case or research questions they explored. A calculation of Tourism and Quality of Life (TQOL) was proposed based on SWB theory (e.g. Andereck et al., 2005; Andereck \& Jurowski, 2006) which comprises only a few of life domains developed by Cummins (1996). Andereck and Nyaupane (2011) improved this measure of TQOL by assembling 38 items according to the specific context of their case. Respondents were asked three sets of questions for each item: how satisfied they were, 
how important they considered it, and to what extent tourism had influenced it, since residents' personalities determine how highly they value each life domain (Ha \& Kim, 2013). A scale measuring total TQOL is similar to scale of importance-performance analysis (see Martilla \& James, 1977; Sever, 2015) and calculated referring to Brown et al (1998).

However, the TQOL scale excluded some widely accepted items of QOL and needed to be revisited. First, health and family life had been included in various other QOL scales (e.g. Nawijn \& Mitas, 2012; Kim et al., 2013; McCabe \& Johnson, 2013; Woo et al., 2015), and even achieved the highest frequency in statistics from Cummins (1996). Family life is an important domain, especially for Chinese people (Shek \& Lee, 2007). Family life could be divided into systemic family functioning and dyadic relationships within the family (Siu \& Shek, 2005), measured against three items: "family relationships," "family activities," and "family income" (e.g. Cummins, 1996; Guo et al., 2013). Education provision, medical facilities, and neighborhood relationships are also significant items for measuring community (Hobson and Dietrich, 1995; Cummins, 1996; Nawijn and Mitas, 2012; Guo and Kim et al., 2013). A community within a harmonious neighborhood and with access to top education and medical facilities can attract wealthier residents and visitors. Therefore, "community medical conditions," "education conditions and development," and "harmonious neighborhood" were also added to the new TQOL scale.

When a community becomes a tourist destination, residents have more contact with tourists and can meet new people, who may become good friends. This contributes to residents' emotional well-being and helps enhance QOL (Neal et al., 2004). Most studies on the effects of tourism showed that tourism development could help improve or upgrade community amenities, such as recreation facilities and parks (Liu \& Var, 1986; Perdue et al., 1987; Lankford \& Howard, 1994). These improvements ensure fairer pricing for leisure facilities in communities. These new facilities mean more jobs and better wages for locals. Therefore, we added four more items to the new 
TQOL scale: "contact with tourists," "opportunities to make new friends," "plenty of parks and open spaces," "fair prices for leisure, entertainment, and tourism," and "high community wages." Water, air, soil, and noise pollution occur frequently in many tourism communities and are closely related to residents' daily lives. Therefore, "quality of soil" and "controlled noise pollution" were added to the new scale as two more items contributing to community well-being. In brief, we added twelve new items to the new TQOL scale (see Table 2).

Secondly, some items of the TQOL scale need to be adjusted due to the new context of our specific case. We combined two original items- "preservation of wildlife habitats" and "preservation of natural areas"-into one item, "preservation of wildlife habitats and natural areas" because in our case investigation, most of the residents we interviewed perceived the natural areas of their community to be exclusively for wildlife. We deleted two items from the original scale, namely, "having live sports to watch in my community," "plenty of festivals, fairs, and museums," because there were no live sports in our case. Moreover, the celebrations of festivals or fairs in China are very different from the case in Arizona, on which that item was based (see Andereck \& Nyaupane, 2011). Festivals, fairs, and museums are often national affairs in China, not reserved for individual communities such as OCT community, and this particular community did not have any celebrations, festivals or fairs that differed from the national ones. Finally, we compiled 49 items for inclusion in the new modified scale of TQOL (see Table 2).

\subsection{Predictors of support for future tourism development}

The predictors of residents' attitudes toward future tourism development are various and complicated. Demographics is the most discussed predictor of residents' attitudes, including sex/gender (e.g. Mason \& Cheyne, 2000; Tosun, 2002; Huh \& Vogt, 2008), education (e.g. McCool \& Martin, 1994; Teye et al., 2002), income (e.g. Haukeland, 1984; Akis et al., 1996), age (e.g. Cavus \& Tanrisevdi, 2003; Huh \& Vogt, 2008), and family structure (including generations and members) (Haralambopoulos 
\& Pizam, 1996). Perdue et al. (1990) provided a classic model to explain the effects of demographics (including age, sex, education, and employment) on residents' support for future tourism development. Several studies tested and extended this model (e.g. Ko \& Stewart, 2002; McGehee \& Andereck, 2004). However, the predictive power of demographic characteristics is inconclusive (McGehee \& Andereck, 2004) and changes according to other factors in a specific case, for example, the capacity for residents to maintain or control the tourism development process (Lankford \& Howard, 1994), the perceived benefit of tourism or positive tourism effects (Ko \& Stewart, 2002; Wang \& Pfister, 2008; Woo et al., 2015), the distance between residents and tourists (Harrill \& Potts, 2003; Woosnam, 2012), and the community's identity or sense of place attachment (McCool \& Martin, 1994; Nunkoo \& Gursoy, 2012). Therefore, demographics should be re-examined in a new case.

Residence characteristics such as length of residency (e.g. Sheldon \& Var, 1984; Lankford \& Howard, 1994; McCool \& Martin, 1994; Haralambopoulos \& Pizam, 1996) and residential status (or home ownership) (Snaith \& Haley, 1999) are also important predictors of residents' attitudes. Sheldon and Var (1984) found that lifelong residents of a community were more sensitive to the influence of tourism and less supportive of tourism while newcomers, who tended to be employed in the tourism sector, appreciated more development in this field. Girard and Gartner (1993) pointed out that long-term residents were less supportive of future tourism development. McCool and Martin (1994) detected the same phenomenon that the longer a resident has lived in the area, the less supportive attitudes toward future tourism development they hold. Snaith and Haley (1999) added that residential status was closely related to residents' attitudes toward tourism development. They found that the newcomer had a more positive attitude toward tourism development than the older residents, and those owning their own homes viewed tourism more positively than those who rented (Snaith \& Haley, 1999). However, is that true in our case of Shenzhen OCT community? 
A stable mutual relationship between tourism development and QOL is widely accepted (Allen et al., 1988; Croes, 2012). A possible effect of QOL on community residents' attitudes toward future tourism development has been suggested in some formal studies, but lacks empirical testing. Lankford and Howard (1994) found in their early empirical study that the more reliance residents felt toward tourists for their economic well-being, the more supportive they were of tourism growth and development. This finding implies that QOL predicts residents' attitudes toward future tourism development, and improvement in the economic domain of QOL has a positive influence on attitudes toward local tourism. Nawijn and Mitas (2012) also found that the residents' attitudes toward tourism related to total QOL in a mostly positive way. Woo et al. (2015) verified through an empirical study that total QOL had a positive influence on residents' attitudes regarding future tourism development. A question for further discussion remains: if tourism development leads to changes in the domains of QOL (Allen et al., 1988; Andereck et al., 2007; Kim et al., 2013), will the different domains of QOL result in distinct attitudes toward future tourism development? Therefore, a general conceptual model of this study is built to examine the predictive power of demographics, TQOL domains and residential status on residents' attitudes toward further tourism development (Figure 1).

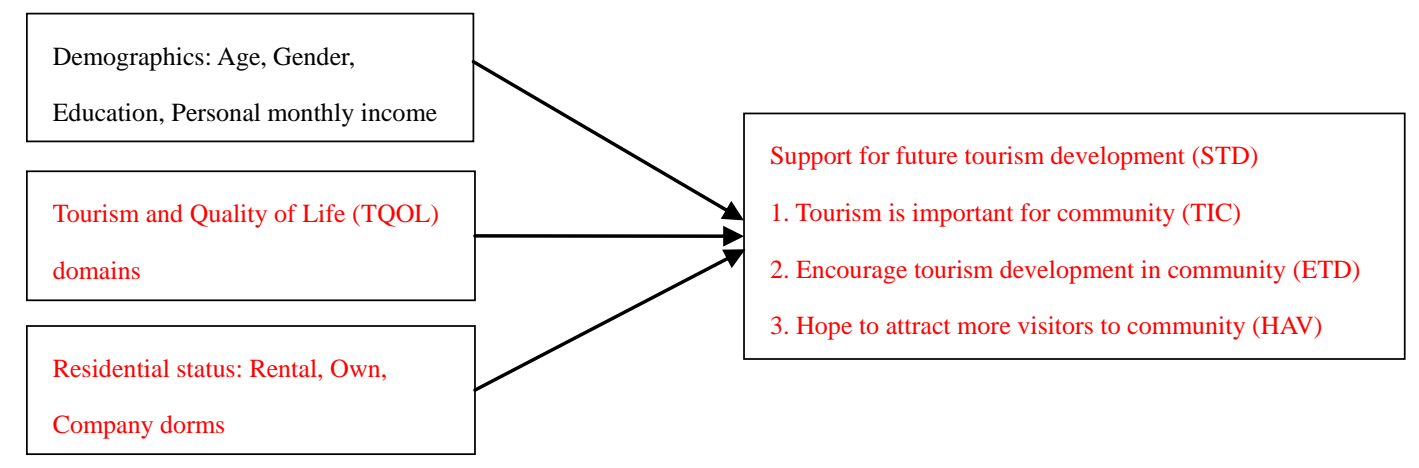

Figure 1. General conceptual model of the study

\subsection{The group and measurement of residents' attitudes}

The attitude of residents toward the development of tourism in their communities is a well-studied area (McGehee \& Andereck, 2004). Many researchers have attempted 
to identify factors that explain residents' attitudes, and some have developed conceptual models for investigating attitudes toward future tourism development (e.g. Liu \& Var, 1986; Perdue et al., 1990; Lankford \& Howard, 1994; Gursoy et al., 2002; Ko \& Stewart, 2002; McGehee \& Andereck, 2004; Dyer et al., 2007; Sharpley, 2014; Maruyama \& Woosnam, 2015). Community residents' perception of or attitude toward the effects of tourism development were measured by a series of single-item or multiple-item scales. Descriptive analysis (Mason \& Cheyne, 2000; Avcikurt \& Soybali, 2001; Sheldon \& Abenoja, 2001), factor analysis (Lankford \& Howard, 1994; McCool \& Martin, 1994; Andereck \& Vogt, 2000; Maruyama \& Woosnam, 2015; Woo et al., 2015) and cluster analysis (Fredline \& Faulkner, 2000; Iroegbu \& Chen, 2001) were used according to the specific research questions.

Residents' attitudes can be divided into four (antagonism, irritation, apathy, and euphoria) (Doxey, 1975) or five (resistance, retreatism, boundary maintenance, revitalization, and adoption) groups (Dogan, 1989). Combinations of various strategies or attitudes may exist simultaneously (Dogan, 1989). Ap and Crompton (1993) detected four attitudes of embracement, tolerance, adjustment, and withdrawal simultaneously within four Texas communities which is at different stages of tourism development and have distinct compositions of residents. Fredline and Faulkner (2000) also identify five groups: ambivalent supporters, haters, realists, lovers and concerned for a reason, among multiple communities in a contiguous urban area of the Gold Coast. However, within a single communities, are there diversity of attitudes and their holders? If yes, and what are the groups of these attitudes?

Support for future tourism development is considered an important domain in attitude scales (Madrigal, 1993; McGehee \& Andereck, 2004; Woo et al., 2015). McGehee and Andereck (2004) developed a scale of eight items to detect residents' attitudes toward future tourism development. Woo et al. (2015) posed three questions to measure attitudes. A more classic model proposed by Perdue et al. (1990) used three constructs with six items as predictors of support for future tourism development 
Madrigal (1993) adjusted this scale and chose these six items as predictors. There are different approval levels of support tourism development among these items. The development of tourism may improve the local economy, residents' QOL, and recreational opportunities, but meanwhile increase traffic problems, property taxes, the crime rate, and the cost of living, in addition to other social space conflicts (Perdue et al., 1990; Lankford \& Howard, 1994; Brunt \& Courtney, 1999). In most cases, these negative effects come from the huge and rapidly growing number of visitors and their behaviors. The use of space and other community facilities by visitors could bring about social, environmental, cultural, and economic clashes. The most serious problem is the increase in living costs for residents, which reduces their QOL and contributes to a lower approval level of tourism development.

The most used item that "tourism is important for the community" (see Perdue et al., 1990; Huh \& Vogt, 2008; Látková \& Vogt, 2012) expresses an obvious and basic approval of tourism development. If someone denies this item, he/she may be opposed to tourism, not only in the future but also at its current stage in his community. If someone declares, "I encourage tourism development in my community," (Wang \& Pfister, 2008; Látková \& Vogt, 2012) they are expressing a high level of support for tourism development and they may regard the current stage of tourism in their community highly, and hope that it will expand in the future. In most cases, the implication of this encouragement is that tourism development brings only positive effects and no negative ones. "I hope to attract more visitors to my community" (see McGehee \& Andereck, 2004; Nunkoo \& Gursoy, 2012) is the highest approval item for tourism development. Generally, the more visitors to an area, the more negative effects are perceived by residents of that area. These three attitudes reflect different levels of support for future tourism development, and were used in our questionnaire.

\section{Research methodology}

\subsection{Study site}

The selection of a study site is important for attitudes study. The stages or levels of 
tourism development in a selected site are significant predictors of residents' attitudes (e.g. Andereck \& Vogt, 2000; Látková \& Vogt, 2012; Hunt \& Stronza, 2013). Madrigal (1993) found that attitudes changed according to the particular stage of tourism development. Shenzhen OCT community in China was chosen as the site for this study based on its mature stage of tourism development and diverse population. The Shenzhen OCT is a representative community with an area of 5.6648 square kilometers and a population of over 50,000. There are two representative characteristics of Shenzhen OCT. First, Shenzhen OCT is a famous national tourist resort located in the urban center of Shenzhen in China. Tourism has developed in the Shenzhen OCT since 1989 (Liang \& Bao, 2012). In that year, the Shenzhen OCT invested 100 million yuan in a theme park project named Splendid China which recovered its initial investment within one year and become a miracle in the history of China tourism industry. Since then, tourism has become an important industry of this community and now it has three theme parks (Shenzhen Happy Valley, Window of the World, and Splendid China Folk Village) and numerous other tourist facilities (Liang \& Bao, 2015). According to the Global Attractions Attendance Report 2013 (published by the Themed Entertainment Association), Shenzhen Happy Valley and Window of the World received 3.28 million and 3.25 million visitors in 2013 and ranked 14th and 15th in the Asia-Pacific region, respectively. The Shenzhen OCT now accommodates nearly 8 million visitors each year.

Second, the Shenzhen OCT is also a tourism gentrified community (Liang \& Bao, 2015) and considered as the most typical case of Tourism-oriented Land Development (TOLD) (Wu \& Xu, 2010) or tourist related real estate (Liang \& Bao, 2015). This community has evolved from a labor-intensive industrial zone with a working-class residential areas to a mature tourist resort with gentrified community within less than 30 years, in the context of the rapid urbanization of Shenzhen city in China. Many residential areas in Shenzhen were built to meet housing needs at different periods (Liang \& Bao, 2015). The average house prices in these residential areas are higher 
than in other areas around. Moreover, within the OCT community, house prices vary considerably from RMB 28,000 (about US \$4,500) to RMB 218,000 (about US $\$ 35,000)$ per square meter. This rapid tourism gentrification of Shenzhen OCT contributes to a mixed community with a certain proportion of low-income residents who service to tourist related enterprises and super-rich or middle class households (Liang \& Bao, 2015). According to the statistics from Liang and Bao (2015), the total population of this community is about 50,000. However, there are more than 2500 employees in three theme parks during the peak season, and 5000 more tourism-related employees in hotels, museum, art centers, and travel agencies. Meanwhile, more than 5000 super-rich and high-level middle class immigrants resided in this gentrified community. This diverse population will help us to perceived different attitudes toward tourism development within one community.

\subsection{Sampling and data collection}

According to the minimum sample size suggested by Anderson and Gerbing (1988), at least 500 samples were needed. Two rounds of quota and convenience sampling were employed to achieve this targeted sample size. Since the large number of questions and complicated options of our questionnaire, a face to face household survey was conducted. Respondents younger than 12 or those educated only to junior high school level were excluded to ensure coherent understanding and usable responses to the questions. Moreover, in order to reduce errors or misunderstanding in reading questions, twelve well trained interviewers were employed to distributed questionnaires to a total of 1,150 households in two different periods of 2014 and 2015 respectively. Quota sampling was carried out according to the population size of each residential area. Because there are about 23 gated residential areas in Shenzhen OCT including low-income neighborhoods and super-rich neighborhoods, and residents who reside in a special residential area show the similar characteristic of their social class. Each of these interviewers was responsible for one or two residential areas. The households were randomly selected within each residential area 
according to the house number, and any visited households in the first round will not be survey again in the second round. Therefore, this way of sampling ensure the visited households are representative of residents from various social class. Finally, of the 616 questionnaires collected, 562 were usable; the remainder were discarded because they contained incomplete and illogical answers. These 562 usable samples were subjected to the final data analysis. The results of reliability analysis (Chronbach's Alpha) illustrated that the Alpha coefficient is 0.974, which is considered acceptable according to Nunnally (1967).

The demographic characteristics of the residents are summarized in Table 1. About $64.4 \%$ of the respondents were between the ages of 19 and 35; these young residents were the main body of the community, while $23.7 \%$ of the respondents were between the ages of 36 and 55, and $3.9 \%$ were 56 or older. The number of female and male residents was about equal among all of the respondents. The majority of the respondents were graduates (56.8\%), with $34.7 \%$ having senior high school or undergraduate degrees, and only $8.5 \%$ holding a post-graduate degree. In terms of personal monthly income, about $28.8 \%$ earned RMB 3,000 or less per month, which puts them in the lower income group. $21.7 \%$ formed a higher income group with a personal monthly income of RMB 10,001 or higher. The majority of respondents (49.5\%) was considered middle class and had a personal monthly income of between RMB 3,001 and RMB 10,000. Around 39.1\% of the respondents were homeowners in the OCT community, $40.6 \%$ rented a house, and the rest, $20.3 \%$, lived in dorms provided by their companies.

Table 1 The demographic and resident characteristics of the respondents $(N=562)$

\begin{tabular}{|c|c|c|c|c|c|}
\hline Variables & $N$ & $\%$ & Variables & $N$ & $\%$ \\
\hline Age & & & Gender & & \\
\hline$\leq 18$ & 45 & $8.0 \%$ & Male & 281 & $50.0 \%$ \\
\hline $19-25$ & 197 & $35.1 \%$ & Female & 281 & $50.0 \%$ \\
\hline $26-35$ & 165 & $29.4 \%$ & Education & & \\
\hline $36-45$ & 95 & $16.9 \%$ & Junior high school level & 48 & $8.5 \%$ \\
\hline
\end{tabular}




\begin{tabular}{lcclcc}
\hline \multicolumn{1}{c}{ 46-55 } & 38 & $6.8 \%$ & Senior high school level & 147 & $26.2 \%$ \\
$\geq 56$ & 22 & $3.9 \%$ & Graduate level & 319 & $56.8 \%$ \\
Personal monthly income(RMB) & & & Post-graduate level & 48 & $8.5 \%$ \\
$\quad \leq 1,500$ & 91 & $16.2 \%$ & Residential status & & \\
$1501-3000$ & 71 & $12.6 \%$ & Rental & 228 & $40.6 \%$ \\
$3,001-5,000$ & 137 & $24.4 \%$ & Own & 220 & $39.1 \%$ \\
$5,001-10,000$ & 141 & $25.1 \%$ & Company dorms & 114 & $20.3 \%$ \\
$10,001-20,000$ & 84 & $14.9 \%$ & & & \\
$\geq 20,001$ & 38 & $6.8 \%$ & & & \\
\hline
\end{tabular}

\subsection{Measurement}

The survey consisted of four sections. The first two sections concerned the demographics (e.g. age, sex, education, and monthly income) and residential status of the respondents. The third section included the three items mentioned in the literature review to measure respondents' attitudes toward future tourism development on a 5-point rating scale $(1=$ strong disagreement with a statement and $5=$ strong agreement). The last section included 49 items measuring importance ( $1=$ "not at all important" and $5=$ to "extremely important"), satisfaction $(1=$ "not at all satisfied" and 5 = "extremely satisfied"), and perceived effects of tourism on QOL (1 = "tourism greatly decreases QOL" and $3=$ "tourism greatly increases QOL"). A series of calculations developed by Brown et al. (1998) and Andereck and Nyaupane (2011) were used to value the level of TQOL from 0 to 60 (see Table 2).

Table 2 Means for TQOL indicators $(N=562)$

\begin{tabular}{|c|c|c|c|c|c|}
\hline Items & Importance $^{a}$ & Satisfaction $^{\mathrm{b}}$ & $\mathrm{QOL}^{\mathrm{c}}$ & Tourism effects $^{\mathrm{d}}$ & TQOL $^{\mathrm{e}}$ \\
\hline The beauty of my community & 4.20 & 3.64 & 12.97 & 2.34 & 30.65 \\
\hline Clean air and water & 4.25 & 3.67 & 13.18 & 2.28 & 30.32 \\
\hline Plenty of park and open space & 4.18 & 3.65 & 13.04 & 2.26 & 30.12 \\
\hline Good public transportation & 4.14 & 3.65 & 12.94 & 2.26 & 29.78 \\
\hline Preservation of wildlife habitats and natural areas & 4.06 & 3.60 & 12.86 & 2.24 & 29.41 \\
\hline Preserving peace and quiet & 4.21 & 3.59 & 12.76 & 2.25 & 29.19 \\
\hline The prevention of crime and vandalism & 4.23 & 3.70 & 12.96 & 2.22 & 29.15 \\
\hline Feeling safe & 4.15 & 3.63 & 12.94 & 2.18 & 28.40 \\
\hline Litter control & 4.23 & 3.48 & 12.22 & 2.28 & 28.18 \\
\hline Quality of soil & 4.20 & 3.51 & 12.43 & 2.23 & 28.15 \\
\hline
\end{tabular}




\begin{tabular}{|c|c|c|c|c|c|}
\hline City services like police and fire protection & 4.06 & 3.58 & 12.63 & 2.18 & 28.04 \\
\hline The image of my community to others & 3.89 & 3.55 & 12.47 & 2.20 & 28.00 \\
\hline The prevention of drug and alcohol abuse & 4.15 & 3.60 & 12.75 & 2.15 & 27.65 \\
\hline Preservation of cultural/historical sites & 3.84 & 3.50 & 12.22 & 2.21 & 27.48 \\
\hline Quality of roads, bridges, and utility services & 4.06 & 3.57 & 12.59 & 2.13 & 27.43 \\
\hline Awareness of natural and cultural heritage & 3.84 & 3.49 & 12.20 & 2.18 & 27.22 \\
\hline Controlled traffic & 4.14 & 3.42 & 11.93 & 2.25 & 27.14 \\
\hline Health & 4.31 & 3.64 & 13.08 & 2.04 & 26.88 \\
\hline Plenty of retail shops and restaurants & 3.97 & 3.51 & 12.26 & 2.15 & 26.84 \\
\hline The prevention of crowding and congestion & 4.08 & 3.39 & 11.78 & 2.24 & 26.80 \\
\hline Family relationships & 4.17 & 3.71 & 13.37 & 1.97 & 26.60 \\
\hline Fair prices for leisure, entertainment and tourism & 3.94 & 3.33 & 11.48 & 2.27 & 26.33 \\
\hline The preservation of my way of life & 4.04 & 3.61 & 12.77 & 2.03 & 26.31 \\
\hline Strong and diverse economy & 3.81 & 3.48 & 12.16 & 2.10 & 25.99 \\
\hline Proper zoning/land use & 3.91 & 3.45 & 11.96 & 2.10 & 25.86 \\
\hline An understanding of different cultures & 3.81 & 3.48 & 11.84 & 2.15 & 25.85 \\
\hline Controlled noise pollution & 4.12 & 3.28 & 11.36 & 2.21 & 25.52 \\
\hline My personal life quality & 3.99 & 3.51 & 12.30 & 2.05 & 25.35 \\
\hline Family activities & 3.93 & 3.50 & 12.34 & 1.99 & 24.76 \\
\hline A feeling of belonging to my community & 3.88 & 3.53 & 12.16 & 1.99 & 24.57 \\
\hline Community pride & 3.60 & 3.47 & 12.04 & 1.98 & 24.47 \\
\hline Controlled urban sprawl and population growth & 3.75 & 3.24 & 11.08 & 2.16 & 24.16 \\
\hline Opportunities to make new friends & 3.56 & 3.39 & 11.81 & 1.99 & 24.10 \\
\hline Fair prices for goods and services & 4.02 & 3.28 & 11.26 & 2.11 & 23.99 \\
\hline Stores and restaurants owned by local residents & 3.61 & 3.30 & 11.38 & 2.04 & 23.79 \\
\hline Family income & 4.04 & 3.35 & 11.61 & 2.03 & 23.63 \\
\hline Education conditions and development & 4.08 & 3.46 & 12.19 & 1.89 & 23.59 \\
\hline Opportunities to participate in local culture & 3.68 & 3.36 & 11.66 & 1.97 & 23.49 \\
\hline Quality recreation opportunities & 3.66 & 3.34 & 11.60 & 1.94 & 23.46 \\
\hline High community wage & 3.73 & 3.31 & 11.40 & 2.02 & 23.45 \\
\hline Community medical conditions & 4.09 & 3.48 & 11.85 & 1.94 & 23.40 \\
\hline A stable political environment & 3.60 & 3.28 & 11.50 & 1.94 & 23.19 \\
\hline Having tourists who respect my way of life & 3.30 & 3.29 & 11.44 & 1.97 & 23.11 \\
\hline Enough good jobs for residents & 3.67 & 3.24 & 11.15 & 2.01 & 23.04 \\
\hline The value of my house and/or land & 3.96 & 3.14 & 10.65 & 2.11 & 22.91 \\
\hline Tax revenue (sales tax/bed tax) & 3.81 & 3.27 & 11.25 & 1.98 & 22.83 \\
\hline Opportunities to contact with tourists & 3.12 & 3.23 & 11.27 & 1.97 & 22.56 \\
\hline
\end{tabular}




\begin{tabular}{|c|c|c|c|c|c|}
\hline The harmonious neighborhood & 3.73 & 3.38 & 11.83 & 1.83 & 22.09 \\
\hline Resident participation in local government & 3.50 & 3.12 & 10.74 & 1.85 & 20.32 \\
\hline
\end{tabular}

A factor analysis to develop TQOL domains was performed. Descriptive statistics were used to show the score of each TQOL domain. A series of multiple linear regression analyses were carried out to further test whether the TQOL domains, demographics, and residential status influenced attitudes toward future tourism development. Finally, a cluster analysis was conducted to detect various attitude groups using the predictors found in the last regression analyses. This study also illustrated the differences of demographics among each attitude groups.

\section{Data analysis and results}

\subsection{TQOL domains in the context of China}

Exploratory factor analysis (EFA) was conducted with the 49 TQOL items using principal component analysis with orthogonal Varimax rotation to identify the underlying TQOL domains. The items "prevention of crime and vandalism," "proper zoning/land use," "opportunities to participate in local culture," "understanding of different cultures," and "strong and diverse economy" were ruled out due to either low factor loading or high overlapping of factors. Therefore, 44 indicators were suitable for analysis. The Kaiser Meyer Olkin overall measure of sampling adequacy was 0.960 , which is labeled "marvelous" by Kaiser (1974). The overall significance of the correlation matrix was 0.000 with a Bartlett test of sphericity chi-square value of 15879.402, suggesting that the data matrix had sufficient correlation to factor analysis. Table 3 provides the results of the final factor analysis. The communalities ranged from 0.420 to 0.731 , suggesting that the variance of the original values was fairly well explained by the common factors.

Table 3 The results of factor analysis

\begin{tabular}{lllll}
\hline Factor & Factor loadings & EV & Variance explained \\
\hline
\end{tabular}




\begin{tabular}{|c|c|c|c|c|}
\hline & & & $\begin{array}{c}\text { (Cumulative variance } \\
\text { explained) }\end{array}$ & alities \\
\hline Urban issues(TQOLURBAN) & & 6.543 & $14.871 \%(14.871 \%)$ & \\
\hline Preserving peace and quiet & 0.771 & & & 0.731 \\
\hline Clean air and water & 0.751 & & & 0.653 \\
\hline Quality of soil & 0.745 & & & 0.646 \\
\hline Plenty of park and open space & 0.740 & & & 0.689 \\
\hline Litter control & 0.720 & & & 0.663 \\
\hline The beauty of my community & 0.682 & & & 0.526 \\
\hline Controlled traffic & 0.644 & & & 0.628 \\
\hline The prevention of drug and alcohol abuse & 0.593 & & & 0.565 \\
\hline The prevention of crowding and congestion & 0.557 & & & 0.592 \\
\hline Community economic strength (TQOLECON) & & 6.352 & $14.436 \%(29.307 \%)$ & \\
\hline Tax revenue (sales tax/bed tax) & 0.752 & & & 0.673 \\
\hline The value of my house and/or land & 0.747 & & & 0.692 \\
\hline Fair prices for goods and services & 0.739 & & & 0.649 \\
\hline Stores and restaurants owned by local residents & 0.669 & & & 0.603 \\
\hline Fair prices for leisure, entertainment and tourism & 0.652 & & & 0.622 \\
\hline Controlled urban sprawl and population growth & 0.645 & & & 0.608 \\
\hline Enough good jobs for residents & 0.641 & & & 0.598 \\
\hline High community wage & 0.595 & & & 0.534 \\
\hline Plenty of retail shops and restaurants & 0.555 & & & 0.533 \\
\hline Controlled noise pollution & 0.555 & & & 0.510 \\
\hline Family and personal well-being(TQOLFAMI) & & 4.619 & $10.497 \%(39.804 \%)$ & \\
\hline Family income & 0.734 & & & 0.635 \\
\hline Family relationships & 0.720 & & & 0.631 \\
\hline Health & 0.718 & & & 0.619 \\
\hline Education conditions and development & 0.664 & & & 0.642 \\
\hline Family activities & 0.652 & & & 0.604 \\
\hline Community medical conditions & 0.624 & & & 0.609 \\
\hline Quality recreation opportunities & 0.517 & & & 0.420 \\
\hline Community well-being(TQOLCOMM) & & 3.768 & $8.564 \%(48.368 \%)$ & \\
\hline Opportunities to contact with tourists & 0.709 & & & 0.599 \\
\hline Opportunities to make new friends & 0.666 & & & 0.576 \\
\hline Preservation of cultural/historical sites & 0.639 & & & 0.654 \\
\hline A stable political environment & 0.631 & & & 0.591 \\
\hline Preservation of wildlife habitats and natural areas & 0.578 & & & 0.657 \\
\hline Feeling safe & 0.518 & & & 0.588 \\
\hline The harmonious neighborhood & 0.518 & & & 0.602 \\
\hline Resident participation in local government & 0.510 & & & 0.610 \\
\hline Way of life(TQOLLIFE) & & 3.186 & $7.241 \%(55.608 \%)$ & \\
\hline Having tourists who respect my way of life & 0.683 & & & 0.682 \\
\hline
\end{tabular}




\begin{tabular}{|c|c|c|c|c|}
\hline The preservation of my way of life & 0.661 & & & 0.705 \\
\hline Community pride & 0.642 & & & 0.660 \\
\hline My personal life quality & 0.635 & & & 0.630 \\
\hline A feeling of belonging to my community & 0.588 & & & 0.603 \\
\hline Community awareness and facilities(TQOLAWAR) & & 2.743 & $6.235 \%(61.844 \%)$ & \\
\hline Awareness of natural and cultural heritage & 0.574 & & & 0.633 \\
\hline Good public transportation & 0.563 & & & 0.625 \\
\hline The image of my community to others & 0.538 & & & 0.622 \\
\hline Quality of roads, bridges, and utility services & 0.535 & & & 0.645 \\
\hline City services like police and fire protection & 0.522 & & & 0.655 \\
\hline
\end{tabular}

The factor analysis resulted in six domains with items that loaded reasonably well and had fairly strong reliability, which explained $61.844 \%$ of the data (Table 3 ). The six domains were (1) urban issues (TQOLURBAN), which includes the quality of (or improvements in) water, air, soil, noise, traffic, and congestion among other urban issues; (2) community economic strength (TQOLECON), which is related to community economic development and its social or economic consequences; (3) family and personal well-being (TQOLFAMI), which is a new domain associated with family life and personal health; (4) community well-being (TQOLCOMM), which concerns the politics of safety, neighborhood relationships, cultural and historical preservation, and contact with visitors and opportunities to meet new people; (5) way of life (TQOLLIFE), which includes five items related to an individual's way of life and sense of belonging; and (6) community awareness and facilities (TQOLAWAR), which includes five items related to community image, infrastructure, and awareness of heritage.

Table 4 The TQOL domains scores

\begin{tabular}{llc}
\hline Domains & Mean & Standard Deviation \\
\hline Urban issues(TQOLURBAN) & 28.69 & 12.53 \\
Community economic strength (TQOLECON) & 24.29 & 10.51 \\
Family and personal well-being(TQOLFAMI) & 24.62 & 11.31 \\
Community well-being(TQOLCOMM) & 24.69 & 10.06 \\
Way of life(TQOLLIFE) & 24.76 & 11.22 \\
Community awareness and facilities(TQOLAWAR) & 28.09 & 12.22 \\
\hline
\end{tabular}

The descriptive statistics showed that the role of tourism in improving the domains of TQOLURBAN (M=28.69) and TQOLAWAR (M=28.09) were rated the highest, 
followed by TQOLLIFE (M=24.76), TQOLCOMM (M=24.69) and TQOLFAMI $(M=24.62)$. However, TQOLECON $(M=24.29)$ had a relatively low rate, which implied that the positive effect of tourism development in promoting community economic and benefit was less perceived and lower valued in Shenzhen OCT, though tourism industry employs a large proportion of community residents.

\subsection{Predictive power on support attitudes for future tourism development}

Five multiple linear regression models were applied to better understand whether the TQOL domains, demographics, and residential status influenced attitudes toward future tourism development (Table 5). The five models were (1) Model 1, which tested the role of demographics on attitude of "support for future tourism development (STD)"; (2) Model 2, which examined the effect of residential status on the attitude of STD; (3) Model 3, which determined the extent to which the various TQOL domains influenced the attitude of STD; (4) Model 4, which tested role of both the demographics and residential status on the general attitudes of STD; and (5) Model 5, which took the demographics and residential status as controlled variables, and examined the effect of TQOL domains on attitudes of STD.

The results, presented in Table 5, indicate that the domain of TQOLURBAN had no significant correlation with any items of attitude, implying that while tourism development may help to improve the quality of the urban area and social order, this improvement has no significant positive influence on residents' attitudes toward future tourism development. This finding challenges traditional views about tourism development and residents' attitudes. According to our interviews with residents, the Shenzhen OCT has been transformed from a traditional rural community located in urban fringe to a new urban center of Shenzhen OCT since 1989. Although tourism development has significant influence on the urban issue, the most important changes were promoted by the rapid urbanization of Shenzhen city in the past three decades (Wang, Wang, \& Wu, 2009; Liang \& Bao, 2015). Rapid urbanization improves and upgrades the urban issue of the whole city, these changes perceived by residents of 
Shenzhen OCT come from not only tourism development but more other city economic driving forces.

Table 5 Results of multiple linear regression analysis

\begin{tabular}{|c|c|c|c|c|c|c|}
\hline & Model 1 & Model 2 & Model 3 & Model 4 & Model 5 & VIF \\
\hline Gender & $0.201(0.908)$ & & & $0.213(0.971)$ & $0.273(1.310)$ & 1.069 \\
\hline Age & $0.012(0.115)$ & & & $0.041(0.410)$ & $0.124(1.287)$ & 1.330 \\
\hline Income & $0.056(0.598)$ & & & $0.082(0.868)$ & $0.048(0.533)$ & 1.720 \\
\hline Education & $-0.375(-2.296)^{*}$ & & & $-0.320(-1.958)$ & $-0.196(-1.248)$ & 1.381 \\
\hline Population & $0.177(2.395)^{*}$ & & & $0.190(2.567)^{*}$ & $0.171(2.428)^{*}$ & 1.527 \\
\hline Generation & $-0.591(-3.379)^{* *}$ & & & $-0.395(-2.078)^{*}$ & $-0.340(-1.884)$ & 1.845 \\
\hline Rental & & $0.919(3.835)^{* * *}$ & & $0.863(3.338)^{* *}$ & $0.828(3.379)^{* *}$ & 1.428 \\
\hline Dorms & & $0.924(3.156)^{* *}$ & & $0.787(2.303)^{*}$ & $0.719(2.213)^{*}$ & 1.682 \\
\hline TQOLECON & & & $0.307(2.994)^{* *}$ & & $0.299(2.951)^{* *}$ & 1.008 \\
\hline TQOLFAMI & & & $0.440(4.279)^{* *}$ & & $0.436(4.274)^{* *}$ & 1.027 \\
\hline TQOLCOMM & & & $0.629(6.145)^{* *}$ & & $0.601(5.847)^{* *}$ & 1.039 \\
\hline TQOLLIFE & & & $0.273(2.666)^{* *}$ & & $0.234(2.307)^{*}$ & 1.015 \\
\hline TQOLAWAR & & & $0.167(1.628)$ & & $0.186(1.830)$ & 1.022 \\
\hline Constant & $11.695(22.041)^{* * *}$ & $10.050(58.771)^{* *}$ & $\begin{array}{c}10.610(103.735)^{*} \\
*\end{array}$ & $10.484(16.354)^{* * *}$ & $9.995(16.341)^{* * *}$ & \\
\hline F-statistic & $2.966 * *$ & $8.822 * *$ & $14.988 * *$ & $3.723^{* *}$ & $7.923 * *$ & \\
\hline R square & 0.031 & 0.031 & 0.119 & 0.051 & 0.158 & \\
\hline Adj R square & 0.021 & 0.027 & 0.111 & 0.037 & 0.138 & \\
\hline$V I F$ & $1.065-1.601$ & 1.210 & 1.000 & $1.065-1.826$ & $1.008-1.845$ & \\
\hline $\mathrm{N}$ & 562 & 562 & 562 & 562 & 562 & \\
\hline
\end{tabular}

Note: ${ }^{*} \mathrm{p} \leq 0.01,{ }^{*} \mathrm{p} \leq 0.05 . \mathrm{STD}=\mathrm{TIC}+\mathrm{ETD}+\mathrm{HAV}$.

(1) The attitude of STD was significantly positively influenced by Population (Model 1, Model 4, \& Model 5) but significantly negatively influenced by Education (Model 1) and Generation (Model $1 \&$ Model 4). These indicates that households with more population show a higher level of support attitude toward tourism development, moreover, ones with higher education or more generations tend to express negative attitude. The average population of each household in Shenzhen OCT is about 3 persons, and most large population (6-8 persons) households are dormitory staffs who mainly service to tourist related enterprises in Shenzhen OCT. These staff residents receive benefits from tourism and support tourism development naturally. The members of this staff households are normally at the same generation while most 
multi-generations households are house owners or tenants who take Shenzhen OCT as a place to live but not to work. Education and other demographics has unstable or insignificant influence on the attitude of STD.

(2) Residential status had significant influence on residents' support for future tourism development (Model 2, Model 4, \& Model 5). Compared with house owners in Shenzhen OCT, tenants and dormitory residents had a more positive attitude of support for future tourism development. Model 1 and Model 4 show that taking the demographics as controlled variables, residential status increase the model explanatory power in $2.0 \%$.

(3) The attitude of STD was significantly and positively affected by the domains of TQOLECON, TQOLFAMI, TQOLCOMM and TQOLLIFE, but insignificantly influence by the TQOLAWAR. This illustrates that a good community image and upgrades to infrastructure may not be induced by tourism development exclusively, while congestion or overuse of the infrastructure may always have tourism development at its core. Tourism development had direct negative effects on community infrastructure but exhibited a positive influence on community image indirectly. TQOLECON, TQOLFAMI and TQOLCOMM are three most important predictors to STD and considered as non-material improvements. They included the increasing economic vitality caused by tourism, more job opportunities and higher wages, more shops, goods, and services, controlled prices of daily necessities and housing, more provisions for family activities and recreation, more opportunities to meet new people, a stable political environment, and a harmonious neighborhood. All improvements were the result of community management and organization, and not only material constructions. Model 4 and Model 5 show that taking the demographics and residential status as controlled variables, TQOL domains increase the model explanatory power in $10.7 \%$.

\subsection{Cluster analysis of residents' support for future tourism development}

K-mean cluster analysis was used to divide residents into four attitude groups who 
express different levels of approving on each items related to attitudes toward future tourism development (Table 6). The groups were neutrals, boosters, realists, and objectors. As the test of homogeneity of variances showed that "TQOLLIFE," "rental," and "yearly resident duration" had significant values $(0.000,0.000$, and 0.002 , respectively) based on the Levene test, these three variates underwent a Kruskal-Wallis test and the other variates were subjected to a one-way ANOVA to test whether the groups with different demographics and levels of TQOL domains had significantly different attitudes of supporting for future tourism development. Post hoc tests applying the methods of LSD were also conducted to compare the differences within each group (Table 7, Table 8).

Table 6 Results of k-mean cluster analysis $(K=4)$

\begin{tabular}{|c|c|c|c|c|c|c|}
\hline \multirow[t]{4}{*}{ Support for tourism development } & Cluster1: & Cluster2: & Cluster3: & Cluster4: & $F$ & Sig. \\
\hline & Neutrals & Boosters & Realists & Objectors & & \\
\hline & $(N=109)$ & $(N=289)$ & $(N=94)$ & $(N=70)$ & & \\
\hline & $19.4 \%$ & $51.4 \%$ & $16.7 \%$ & $12.5 \%$ & & \\
\hline Tourism is important for community & 3 & 4 & 4 & 2 & 475.784 & 0.000 \\
\hline Encourage tourism development in community & 3 & 4 & 3 & 2 & 382.334 & 0.000 \\
\hline Hope to attract more visitors to community & 4 & 4 & 2 & 2 & 361.434 & 0.000 \\
\hline Cluster1:Neutrals & & 1.758 & 1.692 & 2.350 & & \\
\hline Cluster2:Boosters & & & 2.263 & 3.831 & & \\
\hline Cluster3:Realists & & & & 1.971 & & \\
\hline
\end{tabular}

Table 7 Clusters differences by predictive factors

\begin{tabular}{|c|c|c|c|c|c|c|c|}
\hline $\begin{array}{l}\text { Predictive } \\
\text { factors }\end{array}$ & TQOLECON & TQOLFAMI & TQOLCOMM & TQOLLIFE & TQOLAWAR & $\begin{array}{l}\text { Residential } \\
\text { status- rental }\end{array}$ & $\begin{array}{l}\text { Residential } \\
\text { status- dorms }\end{array}$ \\
\hline Neutrals & -0.0757941 & -0.1045661 & -0.0779177 & 268.27 & -0.2270645 & 319.60 & 0.1651 \\
\hline Boosters & 0.0680578 & 0.1254365 & 0.1791482 & 293.06 & 0.0725068 & 290.98 & 0.2145 \\
\hline Realists & 0.0112103 & -0.0402905 & -0.2451867 & 264.61 & 0.0152510 & 239.24 & 0.2340 \\
\hline Objectors & -0.1780133 & -0.3009449 & -0.2890466 & 277.07 & 0.0337422 & 239.76 & 0.1714 \\
\hline$F$ value & 1.401 & 4.146 & 7.390 & & 2.432 & & 0.730 \\
\hline Chi-square & & & & 3.256 & & 24.855 & \\
\hline$p$ value & 0.241 & 0.006 & 0.000 & 0.354 & 0.064 & 0.000 & 0.535 \\
\hline Post hoc test & & $\mathrm{B}>\mathrm{O}$ & $\mathrm{B}>\mathrm{N}$ & & $\mathrm{B}>\mathrm{N}$ & $\mathrm{N}>\mathrm{R}$ & \\
\hline \multirow[t]{3}{*}{ (LSD) } & & $B>N$ & $B>R$ & & & $\mathrm{~N}>\mathrm{O}$ & \\
\hline & & & $\mathrm{B}>\mathrm{O}$ & & & $B>R$ & \\
\hline & & & & & & $\mathrm{B}>\mathrm{O}$ & \\
\hline
\end{tabular}


Table 8 Clusters differences by predictive factors (continued.)

\begin{tabular}{lcccccc}
\hline Demographics & Gender & Age & Education & Personal monthly income & Length of residence & Yearly resident duration \\
\hline Neutrals & 1.42 & 2.73 & 2.55 & 3.17 & 2.48 & 257.24 \\
Boosters & 1.48 & 2.94 & 2.64 & 3.36 & 2.74 & 281.60 \\
Realists & 1.61 & 2.90 & 2.66 & 3.23 & 2.88 & 295.27 \\
Objectors & 1.54 & 3.07 & 2.84 & 3.34 & 3.19 & 300.39 \\
$F$ value & 2.584 & 1.257 & 2.180 & 0.530 & 3.786 & \\
Chi-square & & & & & & 6.571 \\
$p$ value & 0.052 & 0.289 & 0.089 & 0.662 & 0.010 & 0.087 \\
Post hoc test & $\mathrm{R}>\mathrm{N}$ & & $\mathrm{O}>\mathrm{N}$ & & $\mathrm{O}>\mathrm{N}$ & $\mathrm{O}>\mathrm{N}$ \\
\multicolumn{1}{c}{ (LSD) } & $\mathrm{R}>\mathrm{B}$ & & $\mathrm{O}>\mathrm{B}$ & & $\mathrm{O}>\mathrm{B}$ & \\
\hline
\end{tabular}

The "neutral" cluster contained 109 residents, around $19.4 \%$ of all respondents. They were neutral on the role of tourism in the community and encouragement for future development, and agreed slightly that attracting more visitors to the community. The majority of neutrals were male and young, with relatively few educational qualifications and low monthly income. They were tenants or young homeowners of affordable housing, and most had lived in this community for less than three years. They tended to be engaged in tourism-related work and, therefore, felt some of the benefits of tourism development. They were low-level technicians and managers, part-time or casual laborers, and blue-collar workers in both formal and informal tourism sections. "Neutrals" had the second lowest degree of TQOLECON, TQOLFAMI, and TQOLLIFE, the lowest degree of TQOLAWAR, and a relatively high degree of TQOLCOMM. They mostly worked hard but earned little. They mostly perceived minimal benefit from the strengthening community economy via tourism. They felt they had no time or money to enjoy the family activities and community facilities or services (including recreation, hospital, shops, and restaurants) brought in by tourism. They had low pride in their community and little sense of belonging. However, they strived for a harmonious neighborhood and hoped to engage in community affairs. They took this community as a place of earning a living and hoped to be recognized as the actual residents.

"Boosters" formed the largest cluster with 289 residents, over half (51.4\%) of the respondents. They agreed very strongly with all items of support for future tourism 
development. They promoted tourism development positively and hoped it would attract more visitors. They were mostly tenants or dormitory staff of all ages and educational backgrounds, and included old and new residents. Some of them were typical middle class residents. They tended to be middle or junior executives, professionals or service staff, and low-level private entrepreneurs. They scored the highest level of each domain of TQOL. They mainly engaged in tourism-related work and benefited from it. They had enough time and money to participate in family and community activities frequently, and enjoyed their way of life. They loved the community environment and hoped for more respectful visitors. They were positively involved in community affairs and had a strong sense of belonging. They resembled the "lovers" in the research by Fredline and Faulkner (2000). They took this community both for place to earn a living and to live simultaneously.

The "realists" were made up of 94 residents, about 16.7\%. Their response to future tourism development could be described as fairly ambivalent. They exhibited a higher level of disagreement with attracting more visitors but agreed strongly that tourism was important for the community. This implied that they hoped for tourism to continue developing, but did not want to see an increase in visitors. The majority of this cluster was female, either under 25 years old or pensioners. The realists were a polarized group. Some were senior executives, high-level professionals, and retired people with a higher educational background and income, and had owned houses in this community for quite a long time, most more than 10 years. This realists were classified as middle class or "gentlemen" with more than one house in this gentrified community (Liang \& Bao, 2015). They could afford the higher cost of living brought about by the gentrification of the community via tourism. The realists also included clerks, casual laborers, and students with low education and wages, living in rented accommodation or company dormitories, normally for less than three years. This type of realist belonged to a lower social class. All realists had high values of TQOLECON and TQOLFAMI. They felt a sense of economic development and benefit from 
tourism. Tourism development made their lives better and enhanced their family and personal well-being. However, they evaluated the domains of TQOLCOMM, TQOLAWAR, and TQOLLIFE relatively low. Visitors negatively affected their sense of community well-being and changed their ways of life. Fredline and Faulkner (2000) also identified this cluster in their study. Most of these "realists" treated this community as a place to live, some resided here for earning a living and benefited from tourism development.

The "objectors" constituted the minority with only 70 residents, about $12.5 \%$. They exhibited a high level of disagreement with future tourism development. They neither approved of tourism development nor hoped for more visitors. They were absolute haters of tourism development. This cluster showed a roughly equal proportion of female and male respondents, aged mostly between 25 and 45 . The composition of this cluster was quite complicated. Some were the "super rich" with a personal monthly income of more than RMB 20,001 and tended to be senior executives, senior professionals, and private entrepreneurs. They owned more than two houses and had lived there for a few years. Others were retirees with a considerable income and had lived there for more than 20 years. These two kinds of objectors did not earn their living from tourism. They liked peace and quiet and did not want more visitors to disturb their daily lives. The third kind of objector included casual laborers, students, and blue-collar workers engaged in non tourism-related work. They could not enjoy the benefits of tourism but had to endure the negative effects of tourism development on their daily lives, such as the higher cost of living, crowds, traffic congestion, noise and environmental pollution. All of the objectors had the lowest level of TQOLECON, TQOLFAMI and TQOLCOMM, which were negatively affected by tourism development. However, they loved their way of life and exhibited a higher awareness of natural and cultural heritage and higher consideration for the community's infrastructure and services. These objectors were actual residents absolutely and regarded this community as place to live. 


\section{Conclusion and Discussion}

\subsection{Conclusion}

The results of this study provides a more thorough and deeper understanding on the research in tourism development, QOL and resident's attitude. Based on the research of Andereck and Nyaupane (2011), this paper takes a step further by modifying TQOL scale with more reasonable items which did contribute a better explanatory power in most context, especially in the context of China. The main contribution of the study is that the results did show the effect of both residential status and TQOL domains on residents' attitudes to have impact on the future tourism development. In addition to this, this paper is one of the first studies to analyze and compare, in the context of rapid urbanization of China, the explanatory power of TQOL domains and residential status on resident attitudes toward further tourism development. Furthermore, this paper also identifies various attitude groups within one mutual tourism community, and then compares and explains the differences among these attitude groups.

Table 9 The explanatory and predictive powers of each TQOL domains

\begin{tabular}{lccc}
\hline TQOL Domains & Variance explained to TQOL & Mean & Predictive power to STD \\
\hline Urban issues(TQOLURBAN) & $14.871 \%$ & 28.69 & Non-correlation \\
Community economic strength (TQOLECON) & $14.436 \%$ & 24.29 & $0.299(2.951)^{* *}$ \\
Family and personal well-being(TQOLFAMI) & $10.497 \%$ & 24.62 & $0.436(4.274)^{* *}$ \\
Community well-being(TQOLCOMM) & $8.564 \%$ & 24.69 & $0.601(5.847)^{* *}$ \\
Way of life(TQOLLIFE) & $7.241 \%$ & 24.76 & $0.234(2.307)^{*}$ \\
Community awareness and facilities(TQOLAWAR) & $6.235 \%$ & 28.09 & $0.186(1.830)$ \\
\hline
\end{tabular}

Note: ${ }^{* *} \mathrm{p} \leq 0.01,{ }^{*} \mathrm{p} \leq 0.05$

Specifically, the first contribution of this study, therefore, is in developing the TQOL scale by adding new items and modifying the scale according to the new contexts in China. Family and personal well-being (TQOLFAMI) was added as a new domain of the TQOL, which was widely accepted as a common domain of QOL in many early studies (Nawijn \& Mitas, 2012; Kim et al., 2013; McCabe \& Johnson, 
2013; Woo et al., 2015). Moreover, for Chinese people, family life is the core part of QOL, which is deeply influenced by Confucianism in their ways of life. As presented in Table 9, TQOLFAMI had relatively high explanatory power on the TQOL (Variance explained $=10.497 \%$ ) and high predictive power on residents' attitudes (Beta=0.436, $\mathrm{t}=4.274, \mathrm{p}=0.000$ ). These results illustrate that TQOLFAMI is an important domain of TQOL. Among all the TQOL domains, TQOLCOMM (Beta=0.601, $\mathrm{t}=5.847, \mathrm{p}=0.000)$, TQOLFAMI and TQOLECON $($ Beta=0.299, $\mathrm{t}=2.951$, $\mathrm{p}=0.000$ ) are three most important predictors to attitude of support to further tourism development and considered as non-material improvements which is mainly contributed by community management and organizations. However, the mean value of these three TQOL domains are not so high, which implies that respondents express a middle level of satisfaction on non-material domains of TQOL.

In contrast, material improvements such as TQOLURBAN and TQOLAWAR were easily promoted by tourism development and have highest mean values. However, these material improvements had less or no significant influence on residents' attitudes toward future tourism development. The improvements of TQOLURBAN and TQOLAWAR will has some significant and positive effects on total TQOL but contribute less to a positive attitudes. There are two explanations for that. On the one hand, in the context of rapid urbanization of Shenzhen in China, all the material changes were obvious and sharply, mostly promoted by rapid growth of all the economic sectors and continuous urban construction and renewal. Tourism development is just one of these driving forces for the whole city, though it is main driving force for Shenzhen OCT. Therefore, residents valued less the effects of tourism development on community material changes. On the other hand, a good community image and upgrades to infrastructure may not be induced by tourism development exclusively, while congestion or overuse of the infrastructure may always have tourism development at its core. Tourism development had direct negative effects on community infrastructure but exhibited a positive influence on 
community image indirectly.

Furthermore, residential status is also a predictor of residents' attitudes toward future tourism development (Snaith \& Haley, 1999). The results of this study were somewhat different from those of earlier studies. Snaith and Haley (1999) found that home owners viewed tourism more positively than renters. However, this study found that in the Shenzhen OCT, tenants and dormitory residents displayed more positive attitudes toward future tourism development than home owners. There are two explanations for this opposite result. First, the residents' positive attitudes toward tourism development were mainly influenced by whether they engaged in or benefited from tourism development. Shenzhen OCT is a community gentrified by tourism (Liang \& Bao, 2015). Residents who worked in tourism-related sectors, both formally and informally, were considered low or middle income class (Liang \& Bao, 2014). They mainly lived in rental accommodation or company dormitories. They were composed mainly of "neutrals" and "boosters." They took this community as a place to earning a living firstly, and then a place to live secondly. The "super rich" or "gentlemen" owing houses in this community mostly participated in non-tourism work. They are "realists" and "objectors", and regarded this community as place to live firstly.

The other explanation is that home owners, who were considered to have a higher sense of attachment to an area and generally longer length of residence, had a less positive attitude toward tourism development (Sheldon \& Var, 1984; Girard \& Gartner, 1993; McCool \& Martin, 1994). Home owners were overwhelmed by mixed feelings. The more sense of community attachment they displayed, the longer they endured the negative effects of tourism, and the less support for future tourism development. They bought houses and lived there intending to enjoy the beautiful environment and well-served infrastructure bolstered by tourism, but did not want more visitors intruding in their daily lives and could not bear the negative effects of tourism development. 
This result implies that the probability of residents supporting future tourism development depends on how they view their community — as a place to work or as a place to live. If people consider their community as a place to earn a living, they care about whether they can benefit from employment in their community and endure the perceived negative effects of tourism. Those who regard their community primarily as a place to live are more concerned about order, the environment, activities, facilities, and sense of belonging, but they are sensitive to the effects of tourism.

\subsection{Managerial implications}

This study clearly demonstrated that the high level of total TQOL did not always contribute to a more positive attitudes toward future tourism development. Which depends on residents' evaluation of particular TQOL domains. More specifically, non-material improvements in TQOL contribute to more positive attitudes significantly. Therefore, a more effective way to gain residents' support for future tourism development would be to pay more attention to non-material improvements in TQOL. The measurements to enhance the TQOL and to improve the degree of support further tourism development are different. Sometime, you can not have your cake and eat it too. This conclusion can provide a guideline for community officials and planners. If we want greater support for tourism development, we only have to improve the most positive predictive domain of TQOL, not all of them, which can still enhance the effectiveness of our practices in tourism and community development. Furthermore, officials and planners should carefully assess and set up how to target the community via developing tourism. Whether it is a place to earn a living or a place to live, the notions of "community" are quite different and must be considered in the pursuit of higher TQOL and support for future tourism development.

\section{References}

Akis, S., Peristianis, N., \& Warner, J. (1996). Residents' attitudes to tourism development: the case of Cyprus. Tourism Management, 17(7), 481-494. 
Allen, L. R., Long, P. T., Perdue, R. R., \& Kieselbach, S. (1988). The impact of tourism development on residents' perceptions of community life. Journal of Travel Research, 27(16), 16-21.

Andereck, K. L., \& Vogt, C. A. (2000). The relationship between residents' attitudes toward tourism and tourism development options. Journal of Travel Research, 39(1), 27-36.

Andereck, K. L., \& Jurowski, C. (2006). Tourism and Quality of Life. In G. Jennings \& N. P. Nickerson (Eds.), Quality Tourism Experiences (pp. 136-154). London: Elsevier.

Andereck, K. L., \& Nyaupane, G. P. (2011). Exploring the nature of tourism and quality of life perceptions among residents. Journal of Travel Research, 50(3), 248-260.

Andereck, K. L., Valentine, K. M., Knopf, R. C., \& Vogt, C. A. (2005). Residents' perceptions of community tourism impacts. Annals of Tourism Research, 32(4), 1056-1076.

Andereck, K. L., Valentine, K. M., Vogt, C. A., \& Knopf, R. C. (2007). A cross-cultural analysis of tourism and quality of life perceptions. Journal of Sustainable Tourism, 15(5), 483-502.

Anderson, J. R., \& Gerbing, D. W. (1988). Structural equation modeling in practice: a review and recommended two-step approach. Psychological Bulletin, 103(3), 411-423.

Andrews, F. M. (1974). Social indicators of perceived life quality. Social Indicators Research, 1(3), 279-299.

Andrews, F. M., \& Withey, S. B. (1976). Social Indicators of Well-being: Americans' Perceptions of Life Quality. New York: Plenum Press.

Ap, J. (1992). Residents' perceptions on tourism impacts. Annals of Tourism Research, 19(4), 665-690.

Ap, J., \& Crompton, J. L. (1993). Resident strategies for responding to tourism impacts. Journal of Travel Research, 32(1), 47-50.

Aref, F. (2011). The effects of tourism on quality of life: a case study of Shiraz, Iran. Life Science Journal, 8(2), 26-30. 
Avcikurt, C., \& Soybali, H. (2001). Residents' attitudes towards tourism in Ayvalik, Turkey. Tourism Analysis, 6(3), 259-265.

Bimonte, S., \& Faralla, V. (2014). Happiness and nature-based vacations. Annals of Tourism Research, 46, 176-178.

Brown, I. D., Raphael, \& Renwick, R. (1998). Quality of Life Profile Item \#2. Toronto, Canada: Quality of Life Research Unit, Center for Health Promotion, University of Toronto.

Brunt, P., \& Courtney, P. (1999). Host perceptions of sociocultural impacts. Annals of Tourism Research, 26(3), 493-515.

Budruk, M., \& Phillips, R. (2011). Quality-of-life Community Indicators for Parks, Recreation and Tourism Management. Dordrecht: Springer.

Buzinde, C. N., Kalavar, J. M., \& Melubo, K. (2014). Tourism and community well-being: the case of the Maasai in Tanzania. Annals of Tourism Research, 44, 20-35.

Campbell, A., Converse, P. E., \& Rodgers, W. L. (1976). The Quality of American Life: Perceptions, Evaluations and Satisfactions. New York: Russell Sage Foundation.

Cavus, S., \& Tanrisevdi, A. (2003). Residents' attitudes toward tourism development: a case study in Kusadasi, Turkey. Tourism Analysis, 7(3), 259-269.

Chen, Y., Lehto, X. Y., \& Cai, L. (2013). Vacation and well-being: a study of Chinese tourists. Annals of Tourism Research, 42, 284-310.

Croes, R. (2012). Assessing tourism development from Sen's capability approach. Journal of Travel Research, 51(5), 542-554.

Crompton, J. L. (2004). The Proximate Principle: The Impact of Parks, Open Space and Water Features on Residential Property Values and the Property Tax Base (2nd ed). Ashburn, Virginia: National Recreation and Park Association.

Cummins, R. A. (1996). The domains of life satisfaction: an attempt to order chaos. Social Indicators Research, 38(3), 303-328.

de Bloom, J., Geurts, S., \& Kompier, M. (2013). Vacation (after-) effects on employee health and well-being, and the role of vacation activities, experiences 
and sleep. Journal of Happiness Studies, 14(2), 613-633.

Diener, E. (1984). Subjective well-being. Psychological Bulletin, 95(3), 542-575.

Dogan, H. Z. (1989). Forms of adjustment: sociocultural impacts of tourism. Annals of Tourism Research, 16(2), 216-236.

Dolnicar, S., Yanamandram, V., \& Cliff, K. (2012). The contribution of vacations to quality of life. Annals of Tourism Research, 39(1), 59-83.

Doxey, G.V. (1975, Septamber). A causation theory of visitor resident irritants: methodology and research inferences', Paper presented at The Impact of Tourism, The Travel Research Association Proceedings, Sixth Annual Conference, San Diego, California.

Dyer, P., Gursoy, D., Sharma, B., \& Carter, J. (2007). Structural modeling of resident perceptions of tourism and associated development on the Sunshine Coast, Australia. Tourism Management, 28(2), 409-422.

Filep, S., Ross, G. F., \& Pearce, P. L. (2011). Tourists, Tourism and the Good Life. New York: Routledge.

Fredline, E., \& Faulkner, B. (2000). Host community reactions: a cluster analysis. Annals of Tourism Research, 27(3), 763-784.

Gilbert, D., \& Abdullah, J. (2004). Holidaytaking and the sense of well-being. Annals of Tourism Research, 31(1), 103-121.

Girard, T. C., \& Gartner, W. C. (1993). Second home second view: host community perceptions. Annals of Tourism Research, 20(4), 685-700.

Gotham, K. F. (2005). Tourism gentrification: the case of New Orleans' Vieux Carre (French Quarter). Urban Studies, 42(7), 1099-1121.

Guo, Y., Kim, S., \& Chen, Y. (2013). Shanghai residents' perceptions of tourism impacts and quality of life. Journal of China Tourism Research, 10(2), 142-164.

Gursoy, D., Jurowski, C., \& Uysal, M. (2002). Resident attitudes: a structural modeling approach. Annals of Tourism Research, 29(1), 79-105.

Ha, S. E., \& Kim, S. (2013). Personality and subjective well-being: evidence from South Korea. Social Indicators Research, 111(1), 341-359. 
Haralambopoulos, N., \& Pizam, A. (1996). Perceived impacts of tourism: the case of Samos. Annals of Tourism Research, 23(3), 503-526.

Harrill, R., \& Potts, T. D. (2003). Tourism planning in historic districts: attitudes toward tourism development in Charleston. Journal of the American Planning Association, 69(3), 233-244.

Haukeland, J. V. (1984). Sociocultural impacts of tourism in Scandinavia: studies of three host communities. Tourism Management, 5(3), 207-214.

Hobson, J. S. P., \& Dietrich, U. C. (1995). Tourism, health and quality of life. Journal of Travel \& Tourism Marketing, 3(4), 21-38.

Huh, C., \& Vogt, C. A. (2008). Changes in residents' attitudes toward tourism over time: a cohort analytical approach. Journal of Travel Research, 46(4), 446-455.

Hunt, C., \& Stronza, A. (2013). Stage-based tourism models and resident attitudes towards tourism in an emerging destination in the developing world. Journal of Sustainable Tourism, 22(2), 279-298.

Iroegbu, H., \& Chen, J. S. (2001). Urban residents' reaction toward tourism development: do subgroups exist? Tourism Analysis, 6(2), 155-161.

Jurowski, C., Uysal, M., \& Williams, D. R. (1997). A theoretical analysis of host community resident reactions to tourism. Journal of Travel Research, 36(2), 3-11.

Kaiser, H. F. (1974). An index of factorial simplicity. Psychometrika, 39(1), 31-36.

Kim, H., Woo, E., \& Uysal, M. (2015). Tourism experience and quality of life among elderly tourists. Tourism Management, 46, 465-476.

Kim, K., Uysal, M., \& Sirgy, M. J. (2013). How does tourism in a community impact the quality of life of community residents? Tourism Management, 36, 527-540.

Ko, D., \& Stewart, W. P. (2002). A structural equation model of residents' attitudes for tourism development. Tourism Management, 23(5), 521-530.

Kruger, S., Rootenberg, C., \& Ellis, S. (2013). Examining the influence of the wine festival experience on tourists' quality of life. Social Indicators Research, 111, 435-452. 
Lankford, S. V., \& Howard, D. R. (1994). Developing a tourism impact attitude scale. Annals of Tourism Research, 21(1), 121-139.

Látková, P., \& Vogt, C. A. (2012). Residents' attitudes toward existing and future tourism development in rural communities. Journal of Travel Research, 51(1), $50-67$.

Liang, Z. X., \& Bao, J. G. (2012). A seasonal study on tourist flows in theme parks during Golden Weeks: a case of theme parks in Shenzhen Overseas Chinese Town. Tourism Tribune, 27 (1), 58-65.

Liang, Z. X., \& Bao, J. G. (2014). Can urban theme parks increase employment opportunities for local residents: an empirical study of OCT Parks, China. Tourism Tribune, 29 (8), 62 - 69.

Liang, Z. X., \& Bao, J. G. (2015). Tourism gentrification in Shenzhen, China: causes and socio-spatial consequences. Tourism Geographies, 17(3), 461-481.

Liu, J. C., Sheldon, P. J., \& Var, T. (1987). Resident perception of the environmental impacts of tourism. Annals of Tourism Research, 14(1), 17-37.

Liu, J. C., \& Var, T. (1986). Resident attitudes toward tourism impacts in Hawaii. Annals of Tourism Research, 13(2), 193-214.

Lloyd, K. M., \& Auld, C. J. (2002). The role of leisure in determining quality of life: issues of content and measurement. Social Indicators Research, 57, 43-71.

Madrigal, R. (1993). A tale of tourism in two cities. Annals of Tourism Research, 20(2), 336-353.

Martilla, J. A., \& James, J. C. (1977). Importance-performance analysis. Journal of Marketing, 41(1), 77-79.

Maruyama, N., \& Woosnam, K. M. (2015). Residents' ethnic attitudes and support for ethnic neighborhood tourism: the case of a Brazilian town in Japan. Tourism Management, 50, 225-237.

Mason, P., \& Cheyne, J. (2000). Residents' attitudes to proposed tourism development. Annals of Tourism Research, 27(2), 391-411.

Mathieson, A., \& Wall, G. (1982). Tourism, Economic, Physical and Social Impacts. Harlow, UK: Longman. 
McCabe, S., \& Johnson, S. (2013). The happiness factor in tourism: subjective well-being and social tourism. Annals of Tourism Research, 41, 42-65.

McCabe, S., Joldersma, T., \& Li, C. (2010). Understanding the benefits of social tourism: linking participation to subjective well-being and quality of life. International Journal of Tourism Research, 12(6), 761-773.

McCool, S. F., \& Martin, S. R. (1994). Community attachment and attitudes toward tourism development. Journal of Travel Research, 32(3), 29-34.

McGehee, N. G., \& Andereck, K. L. (2004). Factors predicting rural residents' support of tourism. Journal of Travel Research, 43(2), 131-140.

Moscardo, G., Konovalov, E., Murphy, L., \& McGehee, N. (2013). Mobilities, community well-being and sustainable tourism. Journal of Sustainable Tourism, 21(4), 532-556.

Nawijn, J. (2011). Determinants of daily happiness on vacation. Journal of Travel Research, 50(5), 559-566.

Nawijn, J., \& Mitas, O. (2012). Resident attitudes to tourism and their effect on subjective well-being: the case of Palma de Mallorca. Journal of Travel Research, 51(5), 531-541.

Neal, J. D., Sirgy, M. J., \& Uysal, M. (1999). The role of satisfaction with leisure travel/tourism services and experience in satisfaction with leisure life and overall life. Journal of Business Research, 44(3), 153-163.

Neal, J. D., Sirgy, M. J., \& Uysal, M. (2004). Measuring the effect of tourism services on travelers' quality of life: further validation. Social Indicators Research, 69(3), 243-277.

Neal, J. D., Uysal, M., \& Sirgy, M. J. (2007). The effect of tourism services on travelers' quality of life. Journal of Travel Research, 46(2), 154-163.

Nunkoo, R., \& Gursoy, D. (2012). Residents' support for tourism: an identity perspective. Annals of Tourism Research, 39(1), 243-268.

Nunnally, J. (1967). Psychometric Theory. New York: McGraw-Hill.

Perdue, R. R., Long, P. T., \& Allen, L. (1987). Rural resident tourism perceptions and attitudes. Annals of Tourism Research, 14(3), 420-429. 
Perdue, R. R., Long, P. T., \& Allen, L. (1990). Resident support for tourism development. Annals of Tourism Research, 17(4), 586-599.

Prentice, R. (1993). Community-driven tourism planning and residents' preferences. Tourism Management, 14(3), 218-227.

Sever, I. (2015). Importance-performance analysis: a valid management tool? Tourism Management, 48, 43-53.

Sharpley, R. (2014). Host perceptions of tourism: a review of the research. Tourism Management, 42, 37-49.

Sharpley, R., \& Telfer, D. J. (2002). Tourism and development: Concepts and Issues (Aspects of Tourism, 5). Toronto: Channel View Publications.

Shek, D., \& Lee, T. Y. (2007). Family life quality and emotional quality of life in Chinese adolescents with and without economic disadvantage. Social Indicators Research, 80(2), 393-410.

Sheldon, P. J., \& Abenoja, T. (2001). Resident attitudes in a mature destination: the case of Waikiki. Tourism Management, 22(5), 435-443.

Sheldon, P. J., \& Var, T. (1984). Resident attitudes to tourism in North Wales. Tourism Management, 5(1), 40-47.

Sheng, L., \& Tsui, Y. (2010). Foreign investment in tourism: the case of Macao as a small tourism economy. Tourism Geographies, 12(2), 173-191.

Sirgy, M. J. (2010). Toward a quality-of-life theory of leisure travel satisfaction. Journal of Travel Research, 49(2), 246-260.

Sirgy, M. J., Kruger, P. S., Lee, D., \& Yu, G. B. (2011). How does a travel trip affect tourists' life satisfaction? Journal of Travel Research, 50(3), 261-275.

Siu, A. M. H., \& Shek, D. T. L. (2005). Relations between social problem solving and indicators of interpersonal and family well-being among Chinese adolescents in Hong Kong. Social Indicators Research, 71(1-3), 517-539.

Snaith, T., \& Haley, A. (1999). Residents' opinions of tourism development in the historic city of York, England. Tourism Management, 20(5), 595-603.

Teye, V., Sirakaya, E., \& F. Sönmez, S. (2002). Residents' attitudes toward tourism 
development. Annals of Tourism Research, 29(3), 668-688.

Tosun, C. (2002). Host perceptions of impacts: a comparative tourism study. Annals of Tourism Research, 29(1), 231-253.

Uysal, M., Perdue, R., \& Sirgy, M. J. (2012). Prologue: tourism and quality-of-life (QOL) research: the missing links. In M. Uysal., R. Perdue., \& M. J. Sirgy(Eds.), Handbook of Tourism and Quality-of-Life Research: Enhancing the Lives of Tourists and Residents of Host Communities (pp.1-5). London, UK: Springer.

Veenhoven, R. (1991). Questions on happiness: classical topics, modern answers, blind spots. In F. Strack, M. Argyle \& N. Schwarz (Eds.), Subjective Well-being: An Interdisciplinary Perspective (pp.7-26). Oxford: Pergammon Press.

Wang, Y. A., \& Pfister, R. E. (2008). Residents' attitudes toward tourism and perceived personal benefits in a rural community. Journal of Travel Research, 47(1), 84-93.

Wang, Y. P., Wang, Y., \& Wu, J. (2009). Urbanization and informal development in China: urban villages in Shenzhen. International Journal of Urban and Regional Research, 33(4), 957-973.

Woo, E., Kim, H., \& Uysal, M. (2015). Life satisfaction and support for tourism development. Annals of Tourism Research, 50, 84-97.

Woosnam, K. M. (2012). Using emotional solidarity to explain residents' attitudes about tourism and tourism development. Journal of Travel Research, 51(3), 315-327.

Wu, B. H., \& Xu, X. B. (2010). Tourism-oriented land development (TOLD): a new pattern of tourism-real estate development in China. Tourism Tribune, 25(8), 34-38.

Wu, M., \& Pearce, P. L. (2013). Host tourism aspirations as a point of departure for the sustainable livelihoods approach. Journal of Sustainable Tourism, 22(3), 440-460. 